MARKETING AND BRANDING
RESEARCH $\begin{gathered}\text { INDUSTRIAL } \\ \text { MANAGEMENT } \\ \text { INSTITUTE }\end{gathered}$

\title{
Enabling entrepreneurial practices with market-oriented approach: A case study
}

\author{
Keti Ventura*, Haluk Soyuer \\ Department of Business Administration, Ege University, Faculty of Economics and Administrative Sciences, \\ 35040, Bornova, Izmir, Turkey
}

\begin{abstract}
Keywords:

Entrepreneurship,

Intrapreneurship,

Market Orientation

Correspondence:

keti.ventura@ege.edu.tr

The market-oriented approach which includes ensuring a continuous flow of intelligence about customers, market, and competitors to the business to adapt to the ever changing and developing market dynamics and transferring such intelligence to all units of the business to assure quick response to the market, has become very important to gain competitive advantage. The market-oriented approach can be implemented in a business only if there is an organisational culture where all kinds of product/service developments and business process developments that will create a value for customers are supported. An effective implementation of this approach requires both entrepreneurial practices, which are carried out with other businesses and organisations in the external environment and intrapreneurial practices, which are based on encouraging employees in terms of creativity, innovation, idea generation, and developing an organisational climate and management strategies that are appropriate for this. In this regard, the purpose of the current study is to reveal the importance of entrepreneurial activities such as practices supporting market-oriented strategy. Besides, the study aims to explore how such practices are developed in Logo, which is a software company engages in a range of entrepreneurial activities. This paper is designed as an exploratory research employing case study method. Interviews were carried out and documents were examined. This study is anticipated to be beneficial by contributing to establishing entrepreneurship for businesses as a culture. The findings of the study will be a road map for businesses that wish to develop managerial strategies in this matter.
\end{abstract}

CAIMI Journals

Today, in response to the influence of some factors that cannot be controlled by businesses such as intense competition, change in customers' preferences and expectations, market 
uncertainties, and environmental factors, the best solution to gain competitive advantage is to collect the effective internal evaluation of the information about the external environment and later transfer such information into a value properly. A business can be more market-oriented if it can spread the collected information of all its units and integrates such information with its innovative activities in a way that it creates a value for the customers to give a quick response to the market. Likewise, the market orientation is needed for better understanding of the market's needs and expectations and transforming the obtained information into a better value to become a more entrepreneurial business. The purpose of the current study is to show the importance of entrepreneurial activities as practices supporting market-oriented strategy and to demonstrate the entrepreneurial activities of Logo which engages in a range of activities in this field.

\section{The Literature Review}

\section{Market-Oriented Approach in Businesses}

The concept of market orientation refers to the harmonisation of marketing with the business organisation as a business philosophy (Webster, 1992). It is also defined as a set of behaviours whereby marketing is performed (Kohli \& Jaworski, 1990; Kohli, Jaworski, \& Kumar, 1993; Narver \& Slater, 1990; Slater \& Narver, 1994). Market orientation starts with the need felt for market's knowledge (Karahan \& Özçifçi, 2008). According to Kohli \& Jaworski (1990), market orientation includes activities performed by one or more departments to determine customers' current and future needs and the factors influencing them, activities conducted for such needs to be shared by departments with one another, and activities designed by departments through collective and integrated efforts to fulfill such needs. Market orientation can be explained by three concepts including organization-wide generation of market intelligence, dissemination, and responsiveness. It is believed that market intelligence is not only limited to the marketing department, but it is an environmental scanning activity that is performed in all departments of businesses to see the customers and intermediaries' needs. Besides, market intelligence demonstrates how competitors, government policies, laws, technology, and other environmental factors steer customers' preferences. Dissemination is about the recognition of customers by all the departments of R\&D to design, finance, and predict their current and future needs. Responsiveness involves activities that require the active participation of all units of a business such as designing, producing, offering, distributing, and promoting products/services in line with customers' needs and expectations. Narver \& Slater (1990) state that market orientation is composed of three components, namely customer orientation, competitor orientation, and interfunctional coordination. Customer orientation and competitor orientation refer to all the activities that are involved in collecting the information about buyers and competitors in the target market. Inter-functional coordination refers to the coordinated effort of the entire business based on the information about customers and competitors to create a bigger value for the customers.

Implementation of market orientation in businesses depends on various factors. Scholars have suggested different classifications of the factors influencing market orientation. One of the classifications categorises the factors into external factors and internal factors (Raaij \& Stoelhorst, 2008; Tomaskova, 2007). As Tomaskova (2007) puts it, external factors include 
government policies, technological developments, economic factors, customers, suppliers, and competitors, whereas internal factors include top management, organisational structure, organisational strategy, and organisational culture. In another classification, external factors fall into two groups as market dynamics and intense competition (Kohli \& Jaworski, 1990; Pelham \& Wilson, 1995; Pulendran, Speed, \& Widing, 2000; Slater \& Narver, 1994). These factors are generally treated as moderators in the market orientation-performance relationship. Kohli \& Jaworski (1990) argue that market orientation is more important in those markets where market dynamics and customer preferences rapidly change and diversify. Besides, when competition becomes more intense, it is more critical to understand customers' current and future preferences as competition means the existence of various rival products in the market.

Internal factors influencing the market orientation are also categorised in different ways. Jaworski \& Kohli (1993) and Kirca, Jayachandran, \& Bearden (2005) classify them into three groups as top management, interdepartmental factors, and organisational system. Cervera, Molla, and Sanchez (2001) also classify them into top management emphasis, professional attitude, organisational size, and entrepreneurship. Jaworski \& Kohli (1993) emphasise that it is very important for the top management to continuously remind employees the importance of being sensitive and responsive to developments in the market. It is believed that interdepartmental commitment raises market orientation while interdepartmental conflict has negative influences on it. Moreover, a market-oriented reward system and a centralised decision-making system will bring along a strong market-oriented approach, and a structure in which employees' encouragement is quite important for the success of the market orientation.

\section{Entrepreneurship and Market Orientation}

Although entrepreneurship is defined in various ways, it is generally accepted to be a concept that is based on creating opportunities by making innovations (Churchill, 1992). Entrepreneurship is an organisational competency (Bhuiana, Mengucb, \& Bell, 2005) for businesses to have a competitive advantage, profitability, and long-term survival which requires them to develop creative and innovative projects against competitor firms (González-Benito, González-Benito, \& Muñoz-Gallego, 2009). In the literature, innovative, risk-taking, and proactive (Miller, 1983; Kemelgor, 2002; Bhuiana, Mengucb, \& Bell, 2005) aspects of entrepreneurship are featured. Innovation is about new ideas, experiences, and creative processes that can result in new products/services or technological developments. Risk-taking refers to supporting various projects in which possibility of financial failure is taken into account. Proactivity refers to a set of leading behaviours that involve taking measures considering future conditions (González-Benito et al., 2009).

Entrepreneurship can be achieved in a business only with the formation of entrepreneurial mindset across the entire business. Entrepreneurial mindset means being cognitively ready to always look at the world from the perspective of innovation. This mindset can be employed for the emergence of innovative ideas both from the internal and external environment of the business (Kuratko, 2016). Businesses can create new business opportunities by improving their relationships with other businesses and reaching information about external markets 
(Johanson \& Vahlne, 2006). Businesses' relationships and cooperation with the external environment will allow them to reach market information faster and respond to customers' preferences and expectations more appropriately and quickly (i.e. to be more marketoriented). According to the resource-based view, businesses have organisational competencies that transform the sources of information they obtain in the internal or external environment into a value (Hult \& Ketchen, 2001).

The literature contains some studies that take entrepreneurship as an antecedent of market orientation (Matsuno, Mentzer, \& Özsomer, 2002) or as a variable moderating the relationship between market orientation and market performance (Bhuiana et al., 2005). Furthermore, González-Benito et al. (2009) argue that the concepts of entrepreneurship and market orientation complement one another; entrepreneurship needs market orientation for the business' innovative activities in the target market, whereas market orientation needs entrepreneurship to respond to the market opportunities quickly. Matsuno et al. (2002) and Barringer and Bluedorn (1999) state that there is a direct relationship between businesses' proneness to entrepreneurship and market orientation; entrepreneurship involves innovative activities and information collected from the external environment and the analysis of such information have a critical importance for developing innovative strategies.

Although entrepreneurship is mostly addressed within the context of product markets in the literature, factor markets also hold opportunities for entrepreneurship (Shane \& Venkataraman, 2000). Today, especially entrepreneurial businesses procure production factors and other competencies they use for bringing resources together from other businesses or organisations they cooperate in the market. Within the framework of social network approach (Granovetter, 1985), cooperation in the external environment is one of the fundamental ways of creating a value different from competitors for customers and making profitability sustainable. Especially the innovative activities and ideas underlying entrepreneurial activities can be obtained with the flow of information from not only the business itself but also the external environment including universities, research laboratories, suppliers, customers, and other businesses (Powell, Koput, \& Smith-Doerr, 1996). This type of a strategic network formed with the external environment is an important dimension of entrepreneurial behaviour, and especially when it has a proactive structure, it provides opportunities such as offering customers a different value and gaining competitive advantage (Sarkar, Echambadi, \& Harrison, 2001). The above-mentioned network structure allows entrepreneurial businesses to expand their international markets and increase their marketing activities in external markets. This is quite important for strategic decision-making on external environments and assuring the effective use of the resources (Coviello \& Munro, 1995).

Entrepreneurial activities supporting businesses' market-oriented approaches transform market information into a value through the cooperation and network structure they establish with the external environment and their intrapreneurial activities. Intrapreneurship refers to entrepreneurial activities carried out within the internal structure of the business. It is a set of behaviours for renewing the current processes of the business. It refers to a continuous process of innovation covering the entire business that shows parallelism with Kohli and Jaworski's (1990) market-oriented approach. The most important driving force of innovation 
is intrapreneurial practices (Naktiyok \& Kök, 2006). Intrapreneurial practices not only involve creating a new enterprise but also they involve all innovative activities such as developing a new product, service, technology, managerial techniques, strategies, and competitive tactics (Antoncic \& Hisrich, 2003). Adopting a market-oriented approach is highly important for employees to engage in intrapreneurial activities. Market orientation adopted as a culture and learning process (Slater \& Narver, 1995) can be supported by rewarding and encouraging those employees who contribute to innovative processes, act proactively, and can take risks (Sun \& Pan, 2011). Market orientation shapes employees' information processing processes, allows responding to the market quickly, and ensures the development and encouragement of intrapreneurial behaviours within the internal structure of the business (Atuahene-Gima \& Ko, 2001).

\section{Research Questions}

The following research questions guided the study:

- How did the firm create a market-oriented culture?

- What are the entrepreneurial and intrapreneurial activities of the firm that support market-oriented culture?

- How is market information collected and directed to entrepreneurial activities?

- How will a market-oriented entrepreneurial ecosystem be created through the EcoPaas platform?

- How will the Eco-Paas platform contribute to entrepreneurial ecosystem in the business software industry?

\section{Method}

The purpose of the current study is to show the importance of entrepreneurial activities as practices supporting market-oriented strategy and to demonstrate the entrepreneurial activities of Logo which engages in a range of activities in this field. In additin, the study intends to introduce the Eco-Paas system, which is a cloud-based enterprise resource planning platform standing as one of Logo's most important features in recent times, as well as the practices of this platform for creating an ecosystem within a case study. Case study as a research method allows understanding events in-depth (Fidel, 1984) and involves exploring the conceptual structure of events by focusing on a specific topic (Yin, 2011). In the present study, case study covers the practices of Logo which is one of the biggest software businesses of Turkey established in 1984 to expand application software for personal computers. The reason for the selection of the case study is that the Logo's entrepreneurial activities and especially the Eco-Paas platform, which has been developed recently, are suitable for evaluation within the framework of a market-oriented approach. Moreover, this platform offers an infrastructure for creating an ecosystem.

To collect the data, many interviews were carried out with managers, team leaders, and product owners. The secondary data consisting of the documents and reports obtained from the case study were examined. Structured interview technique was used for identifying the parallelisms and differences between the information provided by the individuals having knowledge about the decision problem and making comparisons based on them (Y1ldirım \& 
Şimşek, 2008). Snowball sampling method which is a frequently used method in qualitative research was employed. In this sampling method, the researcher collects contact details about the research subject from various information sources, and he/she is directed to individuals who are related to the subject (Noy, 2008). The Participants of the interviews were carefully selected to assure that they are experienced in entrepreneurial, intrapreneurial, and the EcoPaas platform activities. Interviews were conducted with a total of four managers and team leaders and they were lasted around 45 to 75 minutes. In this paper, the participants' statements are given as quotations conditionally to make them clear to the readers. To increase the validity of the study, the data obtained from the interviews were explained and reported in detail. To increase its reliability, the interview's notes were reviewed by the Logo executives who made appropriate corrections when needed.

The data were analysed through descriptive analysis method. First, the themes under which the data would be evaluated were determined based on the conceptual framework of the study. Next, the interview's notes were organised in accordance with the determined themes, the data were supported by direct quotations, and a coding sheet was created. The coding sheet involved various key codes such as "market orientation", "entrepreneurship", "intrapreneurship", and "ecosystem". Lastly, all the interview's notes were read and the statements concerning each view were coded on the interview coding sheet.

\section{Results}

The findings of the study are summarised under three titles that are the market-oriented approach, entrepreneurship, and Eco-Paas.

\section{Market-Oriented Approach and Product Development}

The logo is a software company and it produces the software products that are adaptable to the languages, business practices, and legal regulations of many countries in the Europe, the Middle East, and the Asia. The products are accessible to users via authorised business partners or duly-authorized distributors in such countries. The Logo offers products/services that are designed for different scales such as enterprise resource planning, industrial software, business intelligence, and e-state practices.

The Logo Company endeavours to achieve a market-oriented approach which is defined as creating a market intelligence for learning customers' current and future needs throughout the business, spreading it across the entire firm and responding to the market based on it (Kohli et al., 1993). The Logo's corporate culture, which is based on the values of quality and efficiency, requires a close monitoring of sectoral developments concerning customers and competitors in the internal and external markets. The Logo used to sell its products through the main distribution centre to the dealers. The distribution centre was defined as the principal Logo customer. However, it was not successful in understanding the customers' wishes and needs and it moved the firm away from them. Recently, the policy of the Logo has changed in a way that it developed its relationship with the dealers to learn the customers' wishes and needs through this channel. Direct identification of customers' needs and demands has become one of the fundamental goals of the firm. The statements of a senior 
executive of the Logo on this topic are presented here as follows (Executive Committee Member-SaaS, Logo):

“...Till recent years' distributors and dealers have been considered our customers. This is not a good method since we do not observe customers' demands ourselves. We cannot get direct information from the customer and thus empathise with their real needs. Design thinking and design driven problem solving have recently been on our agenda. Customization and personalization are quite important customer satisfaction aspects... It is our ambition to provide a 'System of Engagement' instead of the traditional 'System of Records'. Customers should enjoy using our interfaces..."

As the above statement clearly delineates, the Logo found its traditional method incompetent in identifying the customers' needs, collecting their demands, and analysing their wishes within the scope of its policy. Thus, it defined product owners who are the actual owners of the productions with the capacity of collecting and analysing the customers' wishes, needs, or requests from various points of contact, and are able to define functional developments concerning the relevant product. This can be assumed as an example of how customers and top management are engaged in developing a market-oriented approach as stressed by Tomaskova (2007), Kohli \& Jaworski (1990), Pelham \& Wilson, (1995), and Slater \& Narver (1994).

A product owner, specialised in his own product, summarised their methods of collecting information about their customers as follows (Product Owner, Logo):

"...Call centre data, notices delivered to CRM team notices to sales team and dealers, direct notices from customers in the field, demands including legislative regulations, and so on are all entered in the system and gathered by the product owner..."

According to the statements made in the interviews, the functional development demands to collect the information from all points of the customer contact. They are determined by the product owner and his team. Furthermore, sprint planning meetings are held with the technical development team on the possibility of fulfilment of these demands. Product development process consists of the five-week development process and two-week testing process. At the end of the five-week development process, the next sprint meeting is held. The process is demonstrated in Figure 1.

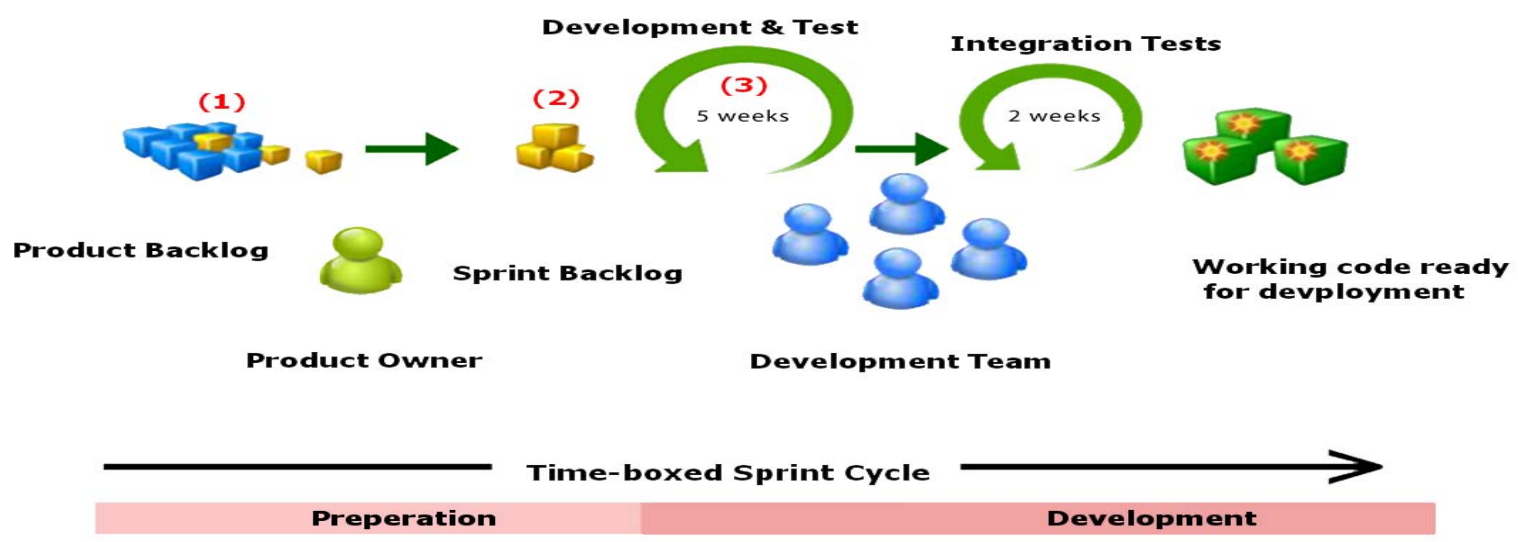

Figure 1. LAPIS (Logo agile process improvement system) process 
Any customer demand about the product turns into a business value by the product owner. $\mathrm{He} / \mathrm{she}$ considers the demand with respect to various parameters including priority of the demand, the necessity of the demand, the frequency of occurrence among customers, availability in the competitor, and financial benefit/loss to be brought by its fulfilment (see Figure 2). Based on this value, the technical development team assigns a story point value to each demand by considering parameters such as the time it takes to complete the development and the number of screens on which it is to be applied. The added-value related to the product is obtained by dividing the above-mentioned two values by one another. In the light of the value obtained, those developments which are selected are considered to create an added-value in the product while other developments are taken into consideration in the next version. Figure 2 displays the business value analysis-sample screen shot.

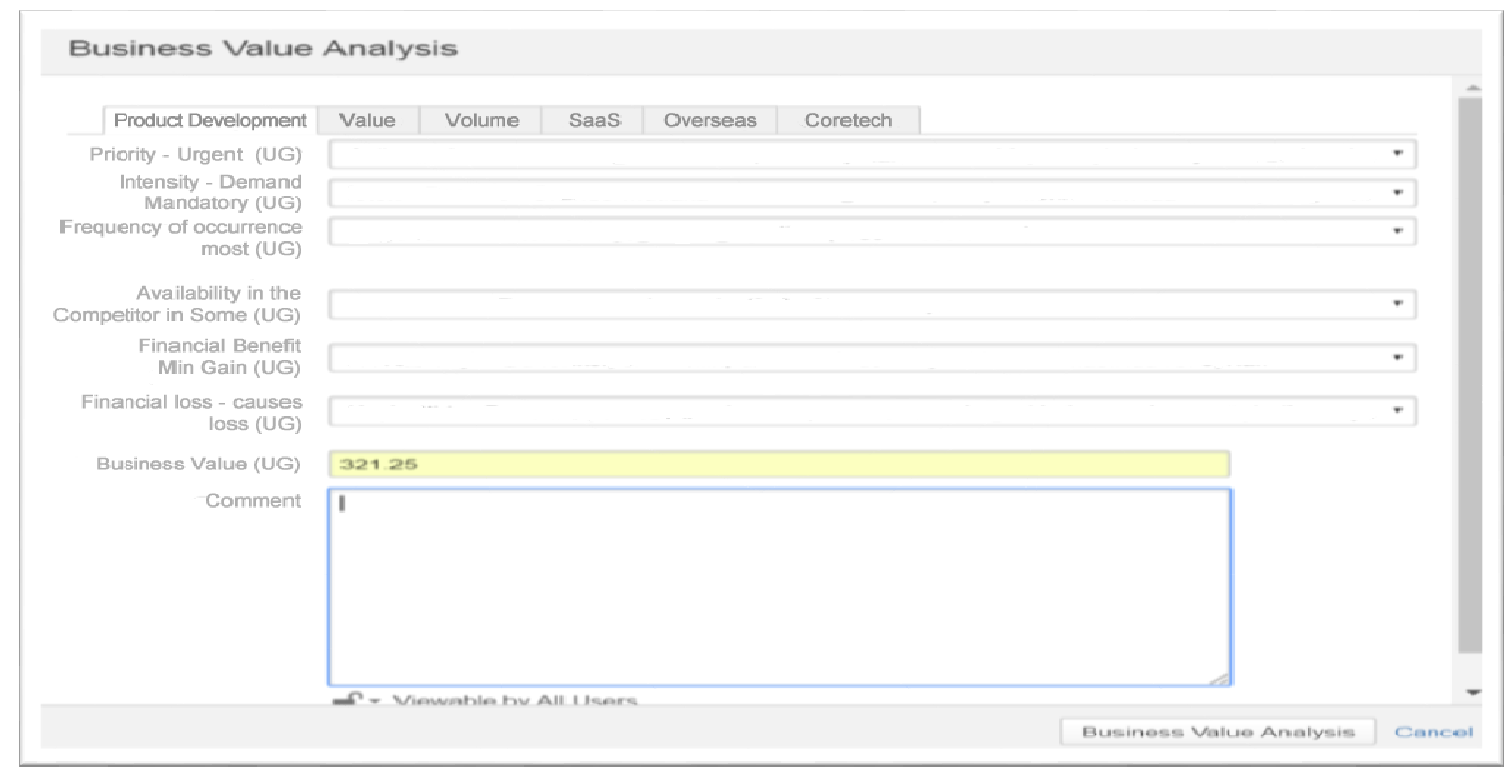

Figure 2. Business value analysis-sample screen shot

It is clear that, in all these processes, the Logo use all points of customer contact to learn customer's needs, wishes, and expectations. The customer's demands are put to the evaluation by functional and technical development teams to be selected. Finally, customer demands or product developments are fulfilled and made at the end of the analysis.

The Logo always monitors rival business software to collect information about competitors and rival products in addition to customers' demands. Information about competitors or new developments is gathered during fairs, seminars, and foreign travels. Such information is evaluated in the firm. It is clear that Logo maintains its activities over the components of the market-oriented approach of Narver \& Slater (1990) that are customer orientation, competitor orientation, and interfunctional coordination.

\section{Entrepreneurial Activities and the Eco-Paas Platform}

Entrepreneurship refers to creative and innovative projects that are carried out by firms to gain competitive advantage, profitability, and long-term survival (González-Benito et al., 2009). The Logo's entrepreneurial activities are addressed under the categories of acquisition/merger, cloud-based enterprise resource planning (Eco-Paas) platform, and intrapreneurial activities. 
In 2011, the Logo acquired Core tech which is one of the prominent technology companies in the industry providing software products as a service (SaaS) over the internet. It also purchased the majority shares of World BI which develops business intelligence software. By the end of 2013, it purchased the rest of the shares. In this way, it had a significant share in the business intelligence market as well as the internet and mobile technologies. The participation of Netsis, which is one of the important players of the local software industry, in September 2013 increased the Logo's competitive position in the Turkish market. Logo Elektronik (e-Logo) was purchased in 2014. In 2015, the Logo purchased all shares ofIntermat Bilişim A.Ş. After it signed an agreement of mutual intention with Sempa and e-Çözüm firms for the purchase of their shares at the beginning of 2015, it purchased all the shares belonging to Sempa Bilgi İşlem Sanayi, which offers solutions in the fields of warehousing, logistics, mobile sales, and production management. In September 2015, all shares of Vardar Software developing software in the area of business processes were transferred to the Logo. With these developments, the Logo gained competitive advantage and had a significant market share in the local software market.

In the related literature, several authors (Cervera, Molla \& Sanchez, 2001; Jaworski \& Kohli, 1993; Kirca et al., 2005) stress that top management's responsiveness to developments in the market is quite important for market orientation; employees should always be informed of this; and interdepartmental dependence increases market orientation. A culture where employees are encouraged is essential for the success of market orientation (Jaworski \& Kohli, 1993) and enables intrapreneurial practices which are carried out by the firm to be improved and supported (Atuahene-Gima \& Ko, 2001). At the Logo, top management attaches great importance to entrepreneurial activities and it is continuously highlighted that this should be settled in the firm as a culture. In this regard, at the Logo, employees internalise the culture of entrepreneurship and they are guided in this direction. A senior executive with whom an interview was conducted summarised this as follows (Executive Committee Member-SaaS, Logo):

"...for an ecosystem to develop in our company, our employees must be a leader in their jobs, eager to perform their jobs no matter what they do, and always think of improving it... We are thinking on how to reward them... Executives, being leaders, must guide and empower their teammates..."

It is stated that the firm has certain policies for development and the selection of human resources based on the culture of innovation and entrepreneurship. In this respect, hackathons have been organised in the firm to encourage employees to make innovations for the last two years. The statement about this is presented as follows (Executive Committee Member-HR, Logo):

"...we hold hackathons for our development teams in summer months. In this way, we conduct a process in which development teams develop team spirit and renew themselves to adapt to the fast-developing world of technology, thereby triggering creativity and innovation within our firm, the leading software business of Turkey..."

It is stated that, at the Logo, hackathons are held in July and involve activities in which employees solve a case individually or as a team. They develop innovation by working on their own projects during the entire month. With such innovations developed, new technical 
platforms are learned that enhances personal development and allows people to improve their competencies and innovation productions. At the end of these processes, the projects are evaluated and rewarded. This motivates the employees in the firm to develop new ideas and projects and encourages intrapreneurship. These kinds of activities help to fulfil customers' needs and expectations and even they can forecast future needs.

One of the most important market-oriented practices at the Logo is cloud-based enterprise resource planning (Eco-Paas) platform, which is still under development. It is a new platform aiming to bring together dealers, solution partners, and other users. It concerned with various technological development activities and enterprise resource planning under a software ecosystem within the framework of the customer-oriented approach. This is a platform that allows the software development process within enterprise resource planning practice to be conducted through cloud computing infrastructure. The cloud computing infrastructure is achieved via a software ecosystem where dealers and (corporate) solution partners are also involved in the process. All the practices developed by stakeholders in this ecosystem can be put up for sale in a marketplace in accordance with cloud business models. Additionally, it is stated that intellectual property rights and licensing conditions concerning the practices developed will be constructed through relevant agreements. This platform is an innovative product as it has been developed with micro-service architecture in the field of enterprise resource planning. The contributions of Eco-Paas platform are expressed as follows (Executive Committee Member-SaaS, Logo):

"With this ecosystem, we would like to offer our dealers, customers, and solution partners a development platform. Eco-Paas is a platform where especially our products and the solutions complementing and extending them can be developed. This is a value-added ecosystem. The system is service-oriented and highly configurable. Development, customization, and personalization are all model-based. This is a huge Java based investment. Developments are made quite easily because their technical infrastructure and models are available in the system. Solution partners do not need to have in-depth knowledge of everything..."

One of the most important properties of the Eco-Paas platform is that its technical infrastructure allows all the practices developed to work in integration with one another. As stated by Sarkar et al. (2001), this kind of a strategic network structure built with stakeholders constitutes an important dimension of entrepreneurial behavior and it is known that such a structure, especially when it is proactive, offers opportunities such as offering customers a different value and gaining competitive advantage. The statement on this matter is presented below (Executive Committee Member-SaaS, Logo):

"...accountants and salespeople have different perspectives on the management of current accounts, especially in the retail industry. While accountants are interested in debts and receivables, salespeople concentrate more on shopping habits, purchase frequencies, and analyses about products. This matters a lot in campaign management. Retail campaign management and industrial campaign management do not consist of the same parameters, but they must work together. Eco-Paas can ensure that they are managed separately, but interact when required. Different business partners can do this through small services, just 
like completing a puzzle. The infrastructure allowing them to contact with one another is ready on this platform. These connections are managed as requested..."

The Logo's Eco-Paas platform is a market-oriented practice that allows them to access market information, to introduce new practices by analysing such information, to respond faster to the customers, and to integrate business partners with one another according to the needs of the market. The statement supporting this view is as follows (Executive Committee Member-SaaS, Logo):

"...when many people in our firm or in the business software industry make developments in accordance with the market needs, they will promote the ecosystem... This is a system where everybody can get as many modules as they want, pay for those which they use, and can use them over the cloud as well... It is very important to reach small customers or new entrepreneurs, besides others. The model is completely cloud here... Many wellknown solution providers have wanted us to get integrated with them, but it is quite costly to learn their systems and create a custom integration. With the availability of Eco-Paas any entity wishing to integrate its services with our own can do so in a single place though industry integration standards. ..."

The logo makes great contributions to the business software industry in Turkey in terms of innovation and entrepreneurship with its market-oriented entrepreneurial activities, marketoriented human resource policies, market-oriented practices, and ecosystem operating in the area of enterprise resource planning that was explained above in detail.

\section{Discussion and Conclusion}

Today, R\&D, innovation, and entrepreneurship in developing markets are very important. Companies endeavours to gain a global competitive advantage and remain in business. In this regard, government policies in Turkey have been revised significantly. In addition to the efforts made in the private sector, public sector, and at universities, many organisations and mechanisms operate and provide support to encourage individual activities in the areas of R\&D, innovation, and entrepreneurship. It is very important that the policies and strategies in this area especially those that are assigned by private sector organisations are designed in a way that supports the implemented policies in the country.

The literature review and the findings obtained through interviews in the present study show that customers' expectations and problems and cooperation with business partners in the external environment have an important share in today's companies' entrepreneurial activities. As highlighted by González-Benito et al. (2009), entrepreneurship and market orientation are two concepts that complement one another. While entrepreneurship needs market orientation for the innovative activities of the business in the target market, market orientation needs entrepreneurship to give fast responses to the market opportunities.

There has been an intense competition in the business software market at national and international levels recently. Thus, it has become very important to understand customers' expectations to develop products/services in line with them and to respond to the market fast. The Logo, which engages in a range of entrepreneurial activities, is one of the innovative software firms of Turkey. The interviews show that entrepreneurship is supported by top management where it involves not only the investments made but also the activities of 
making the human resource profile and business models compatible with entrepreneurship. Within the context of intrapreneurship, hackathon organisations and reward systems motivate employees to improve their personal competencies and develop new products/services that fit the dynamics market.

Entrepreneurial activities and innovations depend on the market information. The logo has introduced product owner system to directly contact with its customers. Through technical departments' analysis of all the market information, new releases or developments are introduced to the market.

With the Eco-Paas platform, the Logo has introduced a new dimension to the domestic business software market in terms of entrepreneurship. This platform is an ecosystem that allows both internal elements and stakeholders to make developments in the area of enterprise resource planning and it ensures that such developments can work in integration with one another. This structure is quite an important innovation for faster fulfilment of the market's needs in the business software industry and for future international competitiveness.

As the case study shows, the Logo concentrates on various entrepreneurial models while implementing this market-oriented strategy. These business models can guide those firms which try to be market-oriented. They are also important as they offer a competitive advantage in the area of business development and innovation.

\section{References}

Antoncic, B. \& Hisrich, R. D. (2003). Clarifying the intrapreneurship concept. Journal of Small Business \& Enterprise Development, 10(1), 7-24.

Atuahene-Gima, K. \& Ko, A. (2001). An empirical investigation of the effect of market orientation and entrepreneurship orientation alignment on product innovation. Organization Science, 12(1), 54-74.

Bhuian, S. N., Menguc, B., \& Bell, S. J. (2005). Just entrepreneurial enough: The moderating effect of entrepreneurship on the relationship between market orientation and performance. Journal of Business Research, 58(1), 9-17.

Cervera, A., Molla, A., \& Sanchez, M. (2001). Antecedents and consequences of market orientation in public organizations. European Journal of Marketing, 35(11/12), 1259-1286.

Churchill, N. C. (1992). Research Issues in Entrepreneurship. In D. L. Sexton \& J. D. Kasarda (Eds.), The state of the art of entrepreneurship (pp. 579-596). Boston, MA: PWS Kent.

Coviello, N. E., \& Munro, H. J. (1995). Growing the entrepreneurial firm: Networking for international market development. European Journal of Marketing, 29(7), 49-61.

González-Benito, Ó., González-Benito, J., \& Muñoz-Gallego, P. A. (2009). The role of entrepreneurship and market orientation in firms' success. European Journal of Marketing, 43(3/4), 500-522.

Granovetter, M. (1985). Economic action and social structure: The problem of embeddedness. American Journal of Sociology, 91(3), 481-510.

Fidel, R. (1984). The case study method: A case study. Library \& Information Science Research, 6(3), 273-288.

Hult, G. T. \& Ketchen Jr, D. J. (2001). Does market orientation matter? A test of the relationship between positional advantage and performance. Strategic Management Journal, 22(9), 899-906.

Jaworski, B., \& Kohli, A. K. (1992). Market orientation: Antecedents and consequences (Working Paper No. 92-104). Marketing Science Institute, Cambridge, MA.

Johanson, J. \& Vahlne, J. E. (2006). Commitment and opportunity development in the internationalization process: A note on the Uppsala internationalization process model. Management International Review, 46(2), 165-178.

Karahan, K. \& Özçiftçi, V. (2008). Pazar yönlülük: Aksaray ili perakende hizmet işletmelerinde bir uygulama. Selçuk Üniversitesi Sosyal Bilimler Enstitüsü Dergisi, 20, 479-492.

Kemelgor, B. H. (2002). A comparative analysis of corporate entrepreneurial orientation between selected firms in the Netherlands and the USA. Entrepreneurship \& Regional Development, 14(1), 67-87. 
Kirca, A. H., Jayachandran, S., \& Bearden, W. O. (2005). Market orientation: A meta-analytic review and assessment of its antecedents and impact on performance. Journal of Marketing, 69(2), 24-41.

Kohli, A. K., \& Jaworski, B. J. (1990). Market orientation: The construct, research propositions, and managerial implications. The Journal of Marketing, 54, 1-18.

Kohli, A. K., Jaworski, B. J., \& Kumar, A. (1993). MARKOR: A measure of market orientation. Journal of Marketing Research, 30, 467-477.

Kuratko, D. F. (2016). Entrepreneurship: Theory, process, and practice. Mason, OH: South-Western Cengage Learning.

Matsuno, K., Mentzer, J. T., \& Özsomer, A. (2002). The effects of entrepreneurial proclivity and market orientation on business performance. Journal of Marketing, 66(3), 18-32.

Miller, D. (1983). The correlates of entrepreneurship in three types of firms. Management Science, 29(7), 770-791.

Narver, J. C., \& Slater, S. F. (1990). The effect of a market orientation on business profitability. Journal of Marketing, 54(4), 20-35.

Naktiyok, A.\&Kök, S. B. (2006). Çevresel faktörlerin iç girişimcilik üzerine etkileri. Afyon Kocatepe Üniversitesi, IIIBF Dergisi, 8(2), 77-92.

Noy, C. (2008). Sampling knowledge: The hermeneutics of snowball sampling in qualitative research, International Journal of Social Research Methodology, 11(4), 327-344.

Pelham, A. M., \& Wilson, D. T. (1995). A longitudinal study of the impact of market structure, firm structure, strategy, and market orientation culture on dimensions of small-firm performance. Journal of the Academy of Marketing Science, 24(1), $27-43$.

Powell, W. W., Koput, K. W., \& Smith-Doerr, L. (1996). Interorganizational collaboration and the locus of innovation: networks of learning in biotechnology. Administrative Science Quarterly, 41(1), 116-145.

Pulendran, S., Speed, R., \& Widing, R. E. (2000). The antecedents and consequences of market orientation in Australia. Australian Journal of Management, 25(2), 119-143.

Raaij, E. M., \& Stoelhorst, J. W. (2008). The implementation of a market orientation: A review and integration of the contributions to date. European Journal of Marketing, 42(11/12), 1265-1293.

Sarkar, M. B., Echambadi, R. A. J., \& Harrison, J. S. (2001). Alliance entrepreneurship and firm market performance. Strategic Management Journal, 22(6/7), 701-711.

Shane, S., \& Venkataraman, S. (2000). The promise of entrepreneurship as a field of research. Academy of Management Review, 25, 217-226.

Slater, S. F., \& Narver, J. C. (1994). Does competitive environment moderate the market orientation-performance relationship? The Journal of Marketing, 58(1), 46-55.

Sun, L. Y., \& Pan, W. (2011). Market orientation, intrapreneurship behavior, and organizational performance: Test of a structural contingency model. Journal of Leadership \& Organizational Studies, 18(2), 274-285.

Tomaskova, E. (2007). The current models of market orientation. European Research Studies, 10(3/4), 81-88.

Webster, F. E. (1992). The changing role of marketing in the corporation. The Journal of Marketing, 56, 1-17.

Yıldırım, A., \& Şimşek, H. (2008). Sosyal bilimlerde nitel araştırma yöntemleri. Journal of Theory \& Practice in Education, $2(2), 113-118$

Yin, R. K. (2011). Applications of case study research. Thousand Oaks, CA: Sage. 